\title{
Hyphessobrycon brumado: a new characid fish (Ostariophysi: Characiformes) from the upper rio de Contas drainage, Chapada Diamantina, Bahia, Brazil
}

\author{
Angela M. Zanata and Priscila Camelier
}

\begin{abstract}
A new species of Hyphessobrycon Ellis is described from tributaries of the upper rio de Contas, Bahia, Brazil. The new species can be diagnosed from its congeners by having low body depth, a broad black stripe along lateral of body that extends weakly through median caudal-fin rays, absence of humeral spot and orange- to reddish life coloration.
\end{abstract}

Uma espécie nova de Hyphessobrycon Ellis é descrita de afluentes do alto rio de Contas, Bahia, Brasil. A espécie nova pode ser diagnosticada de suas congêneres por ter corpo baixo, uma faixa escura larga na lateral do corpo que se estende fracamente pelos raios medianos caudais, ausência de mancha umeral e coloração alaranjada a avermelhada em vida.

Key words: New species, Characidae, Neotropical, Northeastern Brazil, Headwaters.

\section{Introduction}

Hyphessobrycon Durbin is one of the most speciose, widespread and taxonomically poorly known genera of the family Characidae, with more than 120 valid species including a series of recently described ones, distributed from southern Mexico to río de La Plata in Argentina (e.g., Carvalho \& Bertaco, 2006; Bertaco et al., 2007; Benine \& Lopes, 2008; Carvalho et al., 2008; Garzía-Alzate et al., 2010a, 2010b; Miquelarena \& López, 2010). The recognition of groups of species within Hyphessobrycon is based primarily on similarities of color patterns and a hypothesis of its intrarelationships is currently unavailable, except for the rosy tetra clade proposed as monophyletic by Weitzman \& Palmer (1997). Ten species of Hyphessobrycon are currently known from northeastern Brazilian coastal rivers, distributed between Bahia and Ceará States. Four of them were described for drainages in Bahia: H. itaparicensis Lima \& Costa from a small stream in Ilha de Itaparica, H. negodagua Lima \& Gerhard from rio Paraguaçu, $H$. parvellus Ellis from rio Catu and rio Itapicuru, and $H$. vinaceus Bertaco, Malabarba \& Dergam from rio Pardo basin. The remaining northeastern species are somewhat more widespread or occurs just outside the Bahia State, and include $H$. bifasciatus Ellis from eastern Brazilian rivers, including the south of the Bahia State, $H$. iheringi Fowler, H. latus Fowler, and H. piabinhas Fowler from
Fortaleza, Ceará State, and H. micropterus (Eigenmann) and $H$. santae (Eigenmann) from the rio São Francisco basin. Recent collecting efforts in the rio de Contas basin revealed various undescribed fish species, especially from small tributaries of upper portion of the drainage, including a new species of Hyphessobrycon described herein.

\section{Material and Methods}

Counts and measurements were taken according to Fink \& Weitzman (1974) and Menezes \& Weitzman (1990), except for number of horizontal scale rows below lateral line which were counted to the pelvic-fin insertion. Upper scales count of transverse series represents the number of rows of scales between median dorsal row and the lateral line, not including the scale on the median dorsal row or the small scale just below dorsal-fin rays insertion. In the description, the frequency of each count is given in parentheses after the respective count. An asterisk indicates counts of the holotype. Counts of vertebrae, supraneurals, procurrent caudal-fin rays, branchiostegal rays, gill-rakers, dentary teeth and number of tooth cusps were taken only from cleared and stained paratypes (c\&s), prepared according to the method of Taylor $\&$ van Dyke (1985). Dentary and premaxillary bones of one cleared and stained specimen were cleaned from soft tissues for scanning electron micrographs (SEM) images by a short

Departamento de Zoologia, Instituto de Biologia, Universidade Federal da Bahia, Câmpus de Ondina. Rua Barão de Geremoabo, s/n, 40170-290 Salvador, BA, Brazil. a_zanata@yahoo.com.br, pricamelier@yahoo.com.br 
(less than $10 \mathrm{~min}$ ) immersion in weak (less than 1\%) sodium hypochlorite solution and after that air-dried. Vertebrae of the Weberian apparatus were counted as four elements, included in the vertebral counts, and the fused PU1+U1 of the caudal region as a single element. Pattern of circuli and radii was defined on scales sampled from the region between the lateral line and the insertion of the dorsal-fin. Various specimens were dissected for sex confirmation. Institutional abbreviations follow Ferraris (2007), with the inclusion of Universidade Federal da Bahia, Salvador, Bahia, Brazil (UFBA). Specimens utilized for comparative analysis are listed under 'Comparative material' and other comparisons provided elsewhere were based on the literature information (Eigenmann, 1918; Fowler, 1941, 1948; Géry 1977; Lima \& Gerhard, 2001).

\section{Hyphessobrycon brumado, new species} Figs. 1-4

Holotype. MZUSP 101246 (30.7 mm SL, male), Brazil, Bahia, Rio de Contas Municipality, rio Brumado, at Ponte do Coronel, rio de Contas drainage, $13^{\circ} 29^{\prime} 37.0^{\prime \prime} \mathrm{S} 41^{\circ} 52^{\prime} 0.6^{\prime \prime} \mathrm{W}, 1.048 \mathrm{~m}$ a.s.1., $8 \mathrm{Feb}$ 2008, A. M. Zanata, P. Camelier, R. Burger \& A. B. A. Góes.

Paratypes. All from Brazil, Bahia, Rio de Contas Municipality, rio de Contas drainage, rio Brumado. MZUSP 105730, 5, 26.2-30.4 $\mathrm{mm}$ SL, UFBA 4341, 22, 2 c\&s, 25.1-31.6 mm SL, collected with holotype. UFBA 4340, 13, $1 \mathrm{c \& s}, 25.1-26.9 \mathrm{~mm}$ SL, above Cachoeira do Fraga, 1335'54.0"S 4149'44.0”'W, 971 m a.s.1., 8 Feb 2008, A. M. Zanata, P. Camelier, R. Burger \& A. B. A. Góes.

Diagnosis. Hyphessobrycon brumado can be distinguished from its congeners, mainly from other Hyphessobrycon species from northeastern Brazilian drainages $(H$. bifasciatus, $H$. iheringi, $H$. itaparicensis, $H$. latus, $H$. micropterus, $H$. negodagua, $H$. parvellus, $H$. piabinhas, $H$. santae, and $H$. vinaceus) by the presence of a broad black stripe along lateral of body that extends through median caudal-fin rays ( $v s$. absence of broad stripe and/or median caudal-fin rays hyaline in all species cited above except $H$. vinaceus) and absence of humeral spot (vs. presence in H. bifasciatus, H. itaparicensis, $H$. micropterus, $H$. santae, and $H$. vinaceus). Hyphessobrycon brumado can be further distinguished from $H$. bifasciatus by its lower number of branched anal-fin rays (14-17 vs. 25-32) and absence of v-shaped dark lines on body ( $v s$. presence), from $H$. iheringi by having one maxillary tooth (one specimen with zero and one specimen with two) ( $v s$. two teeth), and from $H$. itaparicensis by its lower number of branched anal-fin rays (14-17 vs. 20-26), lower body depth (26.8-30.8\% vs. 34.1-41.9\% of SL), longer caudal peduncle (15.4-18.6\% vs. $7.8-12.1 \%$ of SL), shorter head length (21.2-24.0\% vs. $25.1-30.7 \%$ of SL), shorter pelvic fin (12.0-14.6\% vs. 15.2-19.8\% of SL), and orangeto reddish life coloration ( $v s$. yellowish life coloration). Hyphessobrycon brumado further differs from $H$. micropterus in the lack of a dark blotch on the dorsal fin ( $v s$. dark blotch present) and from $H$. negodagua in the presence of an adipose fin ( $v s$. usually absent; 4 of 158 with adipose fin according to Lima \& Gerhard, 2001), lower body depth (26.8-30.8\% vs. 29.7$36.6 \%$ of SL), relatively lower caudal peduncle depth (26.8$30.8 \%$ vs. $29.7-36.6 \%$ of SL), and overall body coloration clearer, without heavy pigmentation of dark chromatophores over dorsum and posterior portion of body. It further differs from $H$. parvellus by a series of characters, including more scales on the lateral series (33-34 vs. 30-32), lower body depth (26.8-30.8\% vs. $32.4-36.9 \%$ of SL), shorter distance between snout and pectoral-fin origin (22.3-26.2\% vs. 26.8-32.4\% of SL), longer caudal peduncle (15.4-18.6\% vs. $10.3-14.5 \%$ of SL), shorter analfin base (21.3-26.1\% vs. $25.0-32.2 \%$ of SL), shorter anal-fin lobe length (15.1-18.1\% vs. 18.1-24.8\% of SL), shorter head length (21.2-24.0\% vs. 24.4-31.9\% of SL), and distinct overall coloration. Hyphessobrycon brumado can be further distinguished from $H$. santae by having one maxillary tooth (one specimen with zero and one specimen with two (vs. 3-5 teeth) and from $H$. vinaceus by having 5-9 perforated lateral line scales (vs. 10-26).

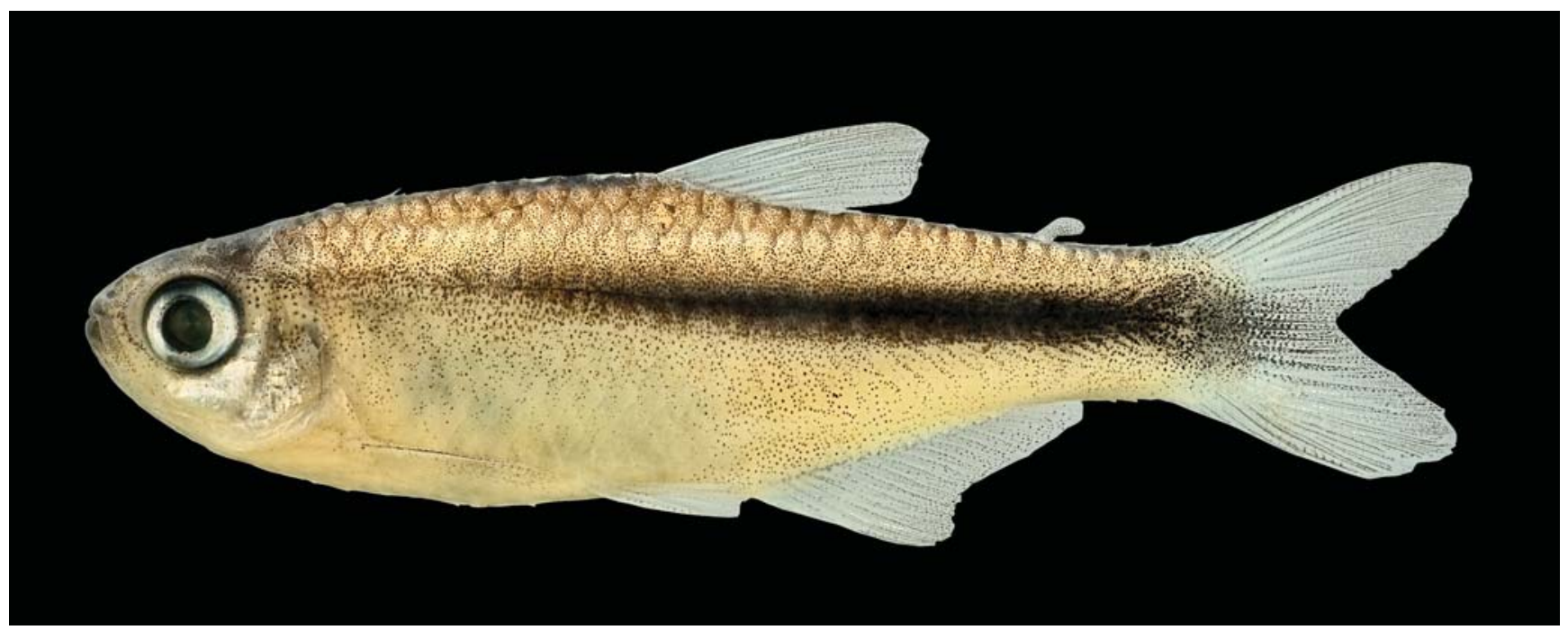

Fig. 1. Hyphessobrycon brumado, holotype, male, MZUSP 101246, 30.7 mm SL, Brazil, Bahia, Rio de Contas Municipality, rio Brumado, at Ponte do Coronel, rio de Contas drainage. 


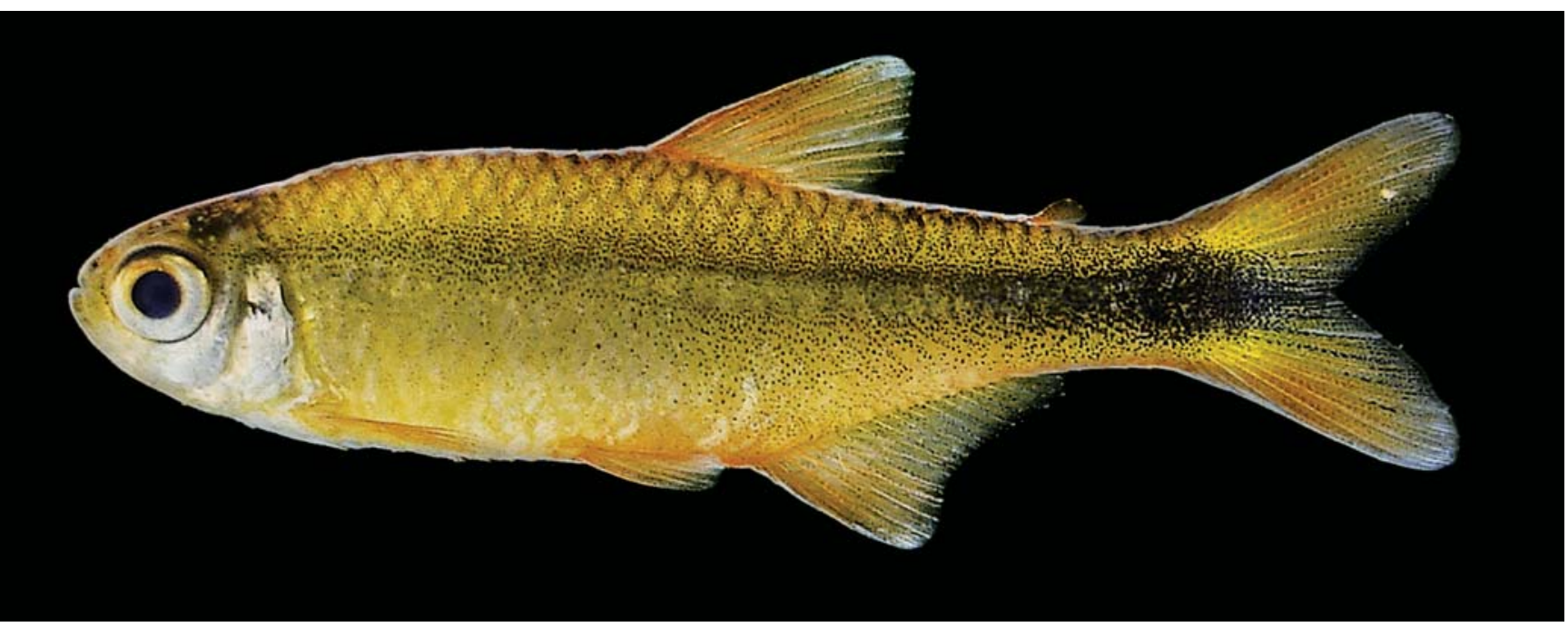

Fig. 2. Hyphessobrycon brumado, paratype, just after fixation, male, UFBA 4341, 29.6 mm SL.

Description. Morphometric data for the holotype and paratypes given in Table 1. Body elongated. Greatest body depth approximately at vertical through pelvic-fin origin. Dorsal profile of head convex from upper lip to vertical through anterior nostrils; straight to slightly convex from latter point to tip of supraoccipital spine and slightly convex from this point to dorsal-fin origin. Body profile straight to somewhat convex along dorsal-fin base; straight from terminus of dorsalfin base to adipose fin; slightly concave between latter point to origin of anteriormost dorsal procurrent caudal-fin ray. Ventral profile of head and body convex from tip of lower lip to anal-fin origin. Body profile along anal-fin base straight and posterodorsally inclined. Ventral profile of caudal peduncle nearly straight to slightly concave.

Head rounded anteriorly in lateral profile; jaws equal in length anteriorly, mouth terminal. Posterior terminus of maxilla barely reaching anterior margin of orbit. Premaxillary with two rows of somewhat narrow teeth, arranged in a gentle archs facing mouth cavity; outer row with $2(2), 3 *(27)$, or 4(1) teeth, bearing 3 cusps; inner row with $4(1)$ or $5^{*}(29)$ teeth bearing 2 , 3 or 5 cusps; symphyseal and three first teeth of inner series asymmetrical or not, if asymmetrical with one cusp on anteromedial side, one larger central cusp and 2 smaller on lateral side; posterior teeth with 3 cusps. Maxilla with $0(1)$, $1 *(28)$, or 2(1) teeth, bearing one or 3 cusps. Dentary with 4 or 5(3) larger and narrow teeth, somewhat anteriorly projected and arranged on a relatively straight line, with 3 or 4 cusps; symphyseal teeth usually with 3 cusps; 5 to 7 diminute teeth with one or 3 cusps follow anterior large teeth, forming straight longitudinal series positioned slightly inner to border of last larger anterior teeth (Fig. 4). First gill arch with $6(3)+1(3)+9(2)$, or 10(1) rakers.

Scales cycloid; circuli absent on posterior margin of scales; none or few slightly poorly developed radii extending to posterior margin of scales. Lateral line incomplete, with $5(1), 6(2), 7(7), 8(10)$, or $9 *(1)$ perforated

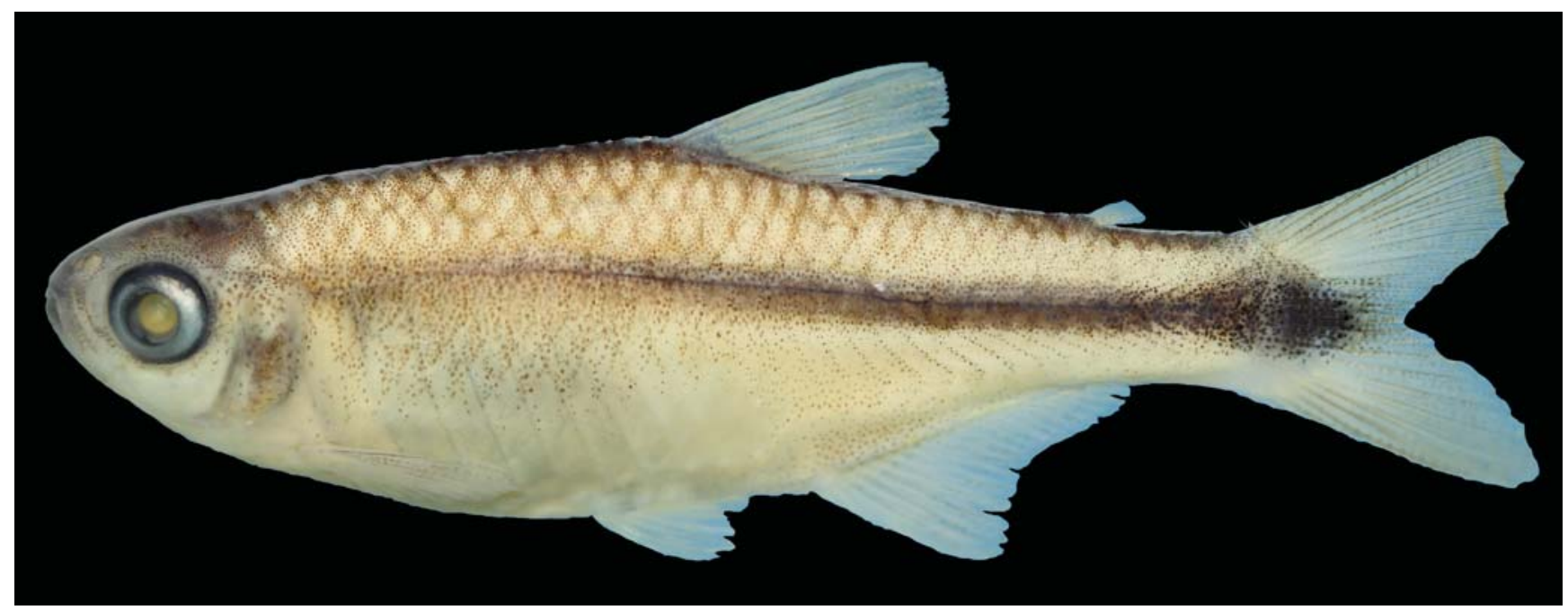

Fig. 3. Hyphessobrycon brumado, paratype, female, UFBA 4341, 29.2 mm SL. 
scales and $33 *(15)$ or $34(6)$ scales on longitudinal series. Horizontal scale rows between dorsal-fin origin and pelvicfin insertion $8(3), 9 *(11)$, or $10(13)$. Scales along middorsal line between tip of supraoccipital process and origin of dorsal fin 9(1), 10*(15), 11(8), or disorganized (3). Horizontal scale rows around caudal peduncle 13(1) or 14*(18). Base of anteriormost anal-fin rays covered by a series of 3-5 scales. Caudal fin not scaled.

Dorsal-fin rays ii, $7, \mathrm{ii}(10)$ or ii, $8, \mathrm{i}^{*}(20)$; distal margin of dorsal fin straight or slightly rounded. Dorsal-fin origin at or slightly posterior to middle of standard length and insertion of last dorsal-fin ray posterior to anal-fin origin; first dorsal-fin pterygiophore inserting behind neural spine of $10^{\text {th }}(2)$ or $11^{\text {th }}(1)$ vertebra. Adipose fin present. Anal-fin rays iii,15(3), iii,16(3), iii,17(1), iv,14(1), iv,15(9), iv,16*(12), or iv, 17(1); distal margin of anal fin slightly concave; first analfin pterygiophore inserting behind haemal spine of $15^{\text {th }}(2)$ or $16^{\text {th }}(1)$ vertebra. Pectoral-fin rays i, 9(8), 10*(17), or 11(5); tip of pectoral fin not reaching vertical through pelvic-fin insertion. Pelvic-fin rays i, $6^{*}(28)$ or $7(1)$. Principal caudalfin rays $10+9(3)$; caudal fin forked, lobes rounded, of similar size. Ten (2) dorsal procurrent caudal-fin rays, and 8(1) or 9(1) ventral procurrent caudal-fin rays. Vertebrae 32(2) or 35(1). Supraneurals 4(1) or 5(2).

Color in alcohol. Overall ground color yellowish (Figs. 1 and 3). Dark chromatophores densely concentrated on dorsal surface of head from upper lip to supraoccipital spine. Infraorbitals and opercle retaining guanine, clear on most of its area, with few relatively large dark chromatophores over area close to orbit and posterior to dorsal portion of eye. Small, dark chromatophores present over anterior half to two-thirds of maxilla. Ventral portion of head less pigmented than dorsal portion; lower lip darkened and portion of head anterior to orbit with scattered dark chromatophores, more concentrated on its median area.

Scales of dorsal portion of body with dark chromatophores, more concentrated along its posterior margin resulting in mild reticulate pattern; reticulate pattern restricted to scales dorsal body half. Humeral region without humeral spot. Dark and relatively broad stripe extends from rear of eye to caudal peduncle; stripe more evident posterior to humeral region and enlarged at end of caudal peduncle, forming rough rounded caudal blotch. Males somewhat darker on posterior portion of body and with caudal blotch more inconspicuous than in females. Caudal blotch extending to median caudal-fin rays, reaching up to 12 rays in males and 6-7 in females. Abdominal region without dark chromatophores.

All fin-rays slightly darkened by presence of dark chromatophores scattered over borders of rays and interradial membranes. Pelvic fin somewhat clearer. Caudal fin somewhat darker, with dark chromatophores on distal portion of rays, mainly on central rays, more evident on mature males. Adipose fin slightly darkened by small dark chromatophores.
Color just after fixation. Overall body coloration orange- to reddish (Fig. 2). Borders of scales on dorsal half of body darkened, forming mild reticulate pattern. Dark, elongated and relatively broad stripe extends from vertical around posterior half of anal fin to median caudal-fin rays; stripe enlarged at end of caudal peduncle, forming roughly rounded caudal blotch. All fins orange- to reddish with scattered dark chromatophores and borders relatively clearer. Males apparently more colored than females.

Sexual dimorphism. The unique dimorphic feature observed externally is related to color pattern. Some males have the lateral stripe broader, the blotch on caudal peduncle with inconspicuous border, and a large number of median caudalfin rays darkened (up to 12) (Fig. 2). Females possess a narrower lateral stripe, a more conspicuous rounded caudal blotch and

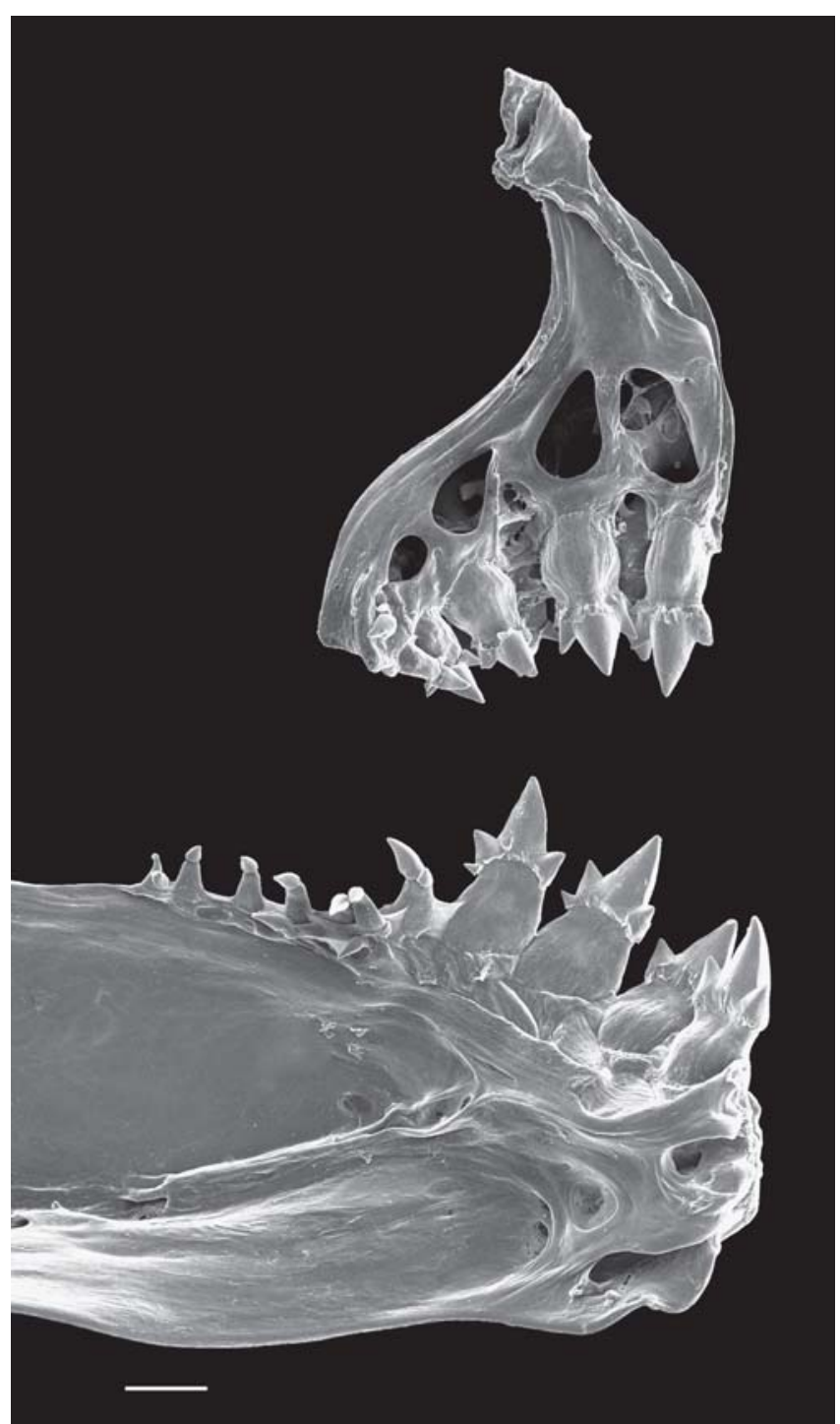

Fig. 4. Hyphessobrycon brumado, paratype, UFBA 4341, 26.0 mm SL; scanning electron micrographs (SEM) showing left premaxillary (top) and dentary teeth (bottom) in mesial view. Scale bar $=100 \mu \mathrm{m}$. Maxilla without teeth in this specimen. 
Table 1. Morphometric data of holotype and paratypes of Hyphessobrycon brumado $(\mathrm{n}=30)$. The range includes the holotype. $\mathrm{SD}=$ Standard deviation.

\begin{tabular}{lcccc}
\hline & Holotype & Range & Mean & SD \\
\hline Standard length (mm) & 30.7 & $25.1-31.6$ & - & - \\
& Percents of Standard length & & & \\
Depth at dorsal-fin origin & 29.0 & $26.8-30.8$ & 28.9 & 1.1 \\
Snout to dorsal-fin origin & 52.4 & $50.6-55.1$ & 52.6 & 1.2 \\
Snout to pectoral-fin origin & 24.8 & $22.3-26.2$ & 24.5 & 0.8 \\
Snout to pelvic-fin origin & 46.9 & $44.6-49.8$ & 47.4 & 1.0 \\
Snout to anal-fin origin & 61.6 & $60.7-65.8$ & 63.5 & 1.3 \\
Caudal peduncle depth & 13.0 & $10.1-13.2$ & 11.6 & 0.8 \\
Caudal peduncle length & 17.3 & $15.4-18.6$ & 16.9 & 0.9 \\
Pectoral-fin length & 20.8 & $17.5-21.4$ & 19.4 & 1.0 \\
Pelvic-fin length & 14.0 & $12.0-14.6$ & 13.4 & 0.7 \\
Dorsal-fin base length & 13.0 & $10.2-14.1$ & 12.2 & 1.0 \\
Dorsal-fin height & 26.4 & $21.4-27.0$ & 23.6 & 1.3 \\
Anal-fin base length & 25.1 & $21.3-26.1$ & 24.0 & 1.3 \\
Anal-fin height & 17.6 & $15.1-18.1$ & 16.7 & 1.0 \\
Eye to dorsal-fin origin & 40.7 & $38.9-42.9$ & 40.8 & 1.1 \\
Dorsal-fin origin to caudal-fin base & 50.8 & $47.6-52.4$ & 50.0 & 1.0 \\
Head length & 23.5 & $21.2-24.0$ & 23.0 & 0.7 \\
& Percents of Head length & & & \\
Horizontal eye diameter & 34.7 & $31.7-40.7$ & 35.6 & 2.0 \\
Snout length & 22.2 & $19.7-27.1$ & 23.2 & 1.6 \\
Least interorbital width & 34.7 & $30.3-37.9$ & 34.1 & 1.7 \\
Upper jaw length & 41.7 & $35.4-45.3$ & 39.6 & 2.4 \\
\hline
\end{tabular}

dark pigmentation of caudal fin usually restricted to six or seven median rays (Fig. 3). These dimorphic traits are not conspicuous in the majority of specimens examined and are much less evident than the dimorphic coloration described for Hyphessobrycon negodagua (Lima \& Gerhard, 2001: figs. 2-3).

Geographic distribution and ecological notes. Hyphessobrycon brumado is known from rio Brumado, tributary of the rio de Contas, a coastal drainage of eastern Brazil (Fig. 5). The species was captured in streams characterized by relatively rapid water current, running over rocky and sandy bottoms at elevate altitudes (971 and 1.048 $\mathrm{m}$ a.s.1.) (Fig. 6). The riparian vegetation is formed by grass, shrubs and trees. Fish species collected with H. brumado are Astyanax aff. lacustris, Gymnotus aff. carapo, Hypostomus sp., Parotocinclus jimi, Poecilia reticulata, Rhamdia aff. quelen, and Trichomycterus sp.

The analysis of stomach contents of three specimens revealed presence of filamentous algae, fragments of vascular plants, adults and two distinct larvae of Diptera (Chironomidae and Simuliidae), larvae of Trichoptera, adult of Formicidae, Aranae, and fragments of unidentified arthropods. Presence of allochthonous arthropods and other autochthonous items suggests that Hyphessobrycon brumado is an omnivorous species with a considerable plasticity on its diet. The broad range of food items of this species diet also suggests that it explores the resources available along the entire water column.

Popular name. Piaba.

Etymology. Named after Brumado, the river where the species is found. A noun in apposition.

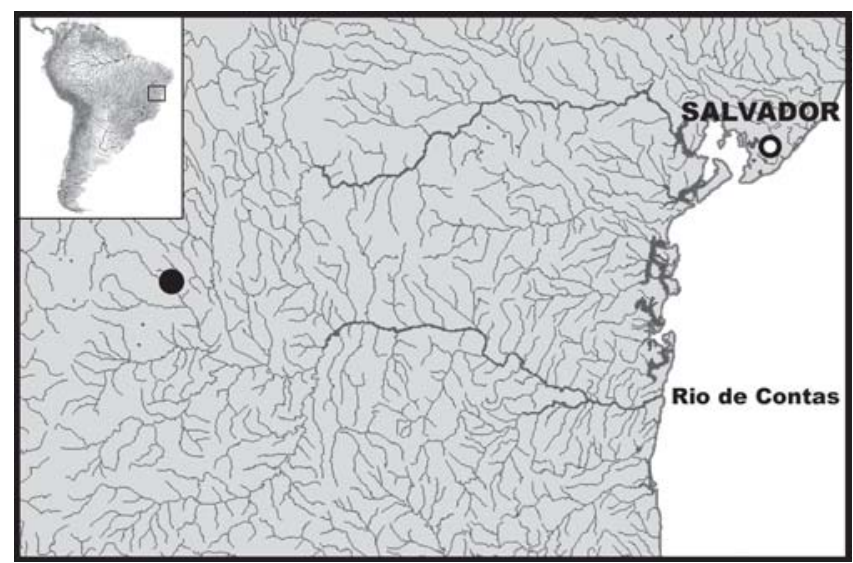

Fig. 5. Portion of northeastern Brazil, showing position of type locality of Hyphessobrycon brumado (black dot), rio Brumado, rio de Contas drainage.

\section{Discussion}

Hyphessobrycon brumado shares a series of characters with $H$. negodagua, described for a headwater of rio Paraguaçu, and $H$. parvellus, described from rio Catu (rio Pojuca drainage). The three species are from coastal drainages of Bahia State and could be interpreted as putatively closely related on the basis of its elongated body, reduced layer of musculature between first and second ribs (more evident on H. parvellus), absence of humeral spot, absence of a well defined caudal spot (mainly in males), together with sexually dimorphic coloration of caudal region. Lima \& Gerhard (2001) pointed out that the color pattern is a good starting point to elucidate the complex systematic of Hyphessobrycon and related genera, and a comparison of these traits for the three cited species seems pertinent.

The dimorphic color pattern of $H$. negodagua was described in detail by Lima \& Gerhard (2001), with mature

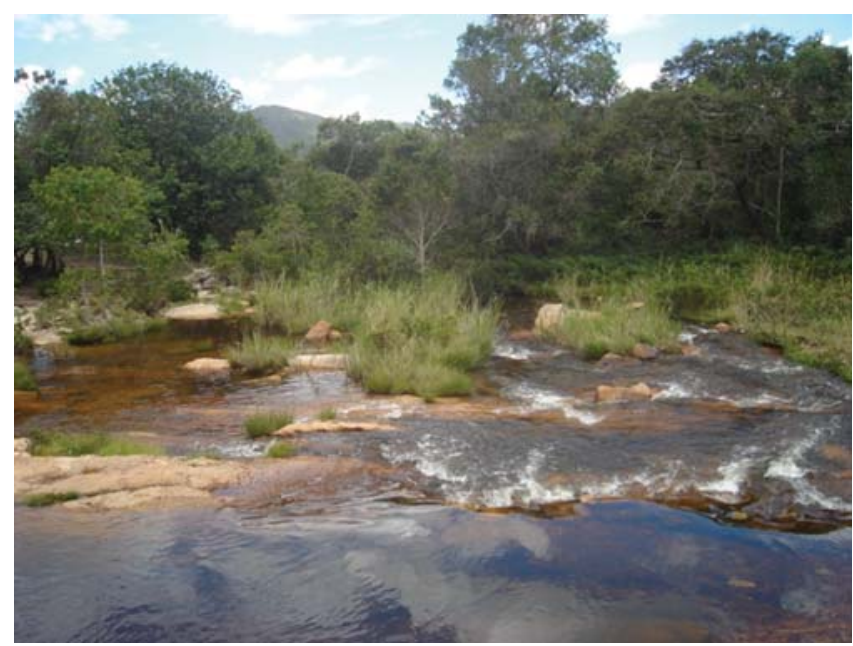

Fig. 6. Type locality of Hyphessobrycon brumado, Brazil, Bahia, Rio de Contas Municipality, rio de Contas drainage, rio Brumado, at Ponte do Coronel. 
males being predominantly darker in life, usually much darker than females, with a denser concentration of dark chromatophores on the caudal fin forming a diffuse blotch on the caudal peduncle, and a midlateral stripe less evident. According to the authors the coloration of H. negodagua is unique among the species of the genus known until that date, with the possible exception of $H$. parvellus. Examination of specimens of $H$. parvellus more recently collected in the rio Pojuca drainage, eastern Bahia State, revealed a color pattern somewhat similar to H. negodagua, mainly by the absence of a humeral spot, absence of a well defined caudal spot, presence of dark chromatophores scattered over body and fins, and dorsal and anal fins with distal portions of first rays white in life. Males and females of H. brumado also have dimorphic coloration, in a pattern similar to that described for the two species above. Males of the species are usually somewhat darker, with concentration of dark chromatophores on the posterior portion of body forming an inconspicuous caudal peduncle blotch, while females possess a rounded caudal blotch and dark pigmentation more restricted to fewer median caudal-fin rays (6-7 vs. 12 rays in males). It is noteworthy that the dimorphic color traits of $H$. brumado are not conspicuous for the majority of specimens examined and are much less evident than the pattern described for $H$. negodagua. Notwithstanding, although possessing a series of similarities in color pattern, at least the males of the three species differ in details of this coloration. Mature males of $H$. parvellus are not as darkened as $H$. negodagua and possess all fins completely red, with the exception of the caudal fin that has most of its median rays darkened, and tip of dorsal and anal fins white, while the females of both species are more alike, with a more discrete rounded spot over caudal peduncle and fewer median caudal-fin rays darkened. The same pattern occurs on females of $H$. brumado, while males of the species differs from $H$. negodagua and $H$. parvellus by having orange- to reddish coloration of body and fins in life, posterior portion of body not as darkened as $H$. negodagua and fewer darkened caudal-fin rays than $H$. parvellus.

According to Lima \& Gerhard (2001), one of the main differences between $H$. negodagua and $H$. parvellus is related to the absence of adipose fin in the former. However, examination of specimens tentatively identified as $H$. parvellus recently collected in various coastal drainages of Bahia State has revealed presence of adipose fin as polimorphic, mainly on specimens of rio Paraguaçu drainage. A more precise definition of $H$. parvellus and the clear limit between it and $H$. negodagua depends on an extensive examination of these two species, a task under way by one of the authors (AMZ).

Recent collecting efforts on several coastal drainages on Bahia State has indicated that H. brumado and H. negodagua are apparently restricted to headwaters of rio de Contas and rio Paraguaçu, respectively, while $H$. parvellus is more broadly distributed, from rio Real on the extreme north Bahia to rio de Contas, on central portion of Bahia State. Similarly to rio Paraguaçu, the rio de Contas has a substantial endemic component on its ichthyofauna, although even less known taxonomically. Species apparently endemic to this basin includes Hasemania piatan Zanata \& Serra, Parotocinclus jimi Garavello, and at least six new species in process of description.

Hemigrammus brevis Ellis and H. gracilis (Lütken) are small characids species from São Francisco River basin somewhat similar to $H$. brumado. Beyond the presence of scales covering part of caudal-fin lobes, these two Hemigrammus species also differs from $H$. brumado in features of coloration and overall external morphology. In life, both Hemigrammus species lack the orange- to reddish body coloration of $H$. brumado. In alcohol, no dark lateral stripe is visible in Hemmigrammus brevis and a large dark elongated blotch over caudal peduncle is present, usually extending to median caudal-fin rays, and $H$. brevis has also relatively deeper body $(30.5-36.0 \%$ vs. $26.8-30.8 \%$ in $H$. brumado). From $H$. gracilis, the new species differs by having the lateral stripe reaching the end of caudal peduncle and dark pigmentation over median caudal-fin rays ( $v s$. end of caudal peduncle clear, without dark pigmentation over median caudal-fin rays) and smaller eye diameter (31.7-40.7\% vs. 43.9-51.7\% of HL). Furthermore, males and females of both cited species of Hemigrammus apparently have similar coloration, not showing the sexually dimorphic pattern observed in H. brumado.

Comparative material. All from Brazil, Bahia State. Hemigrammus brevis, UFBA 165, 93, 10, 15.9-21.7 mm SL, rio São Francisco basin. Hemigrammus gracilis, UFBA 5457, 10, $19.7-$ $23.5 \mathrm{~mm}$ SL, rio São Francisco basin. Hyphessobrycon bifasciatus, UFBA 4971, 19, 16.3-33.4 mm SL, rio Jucuruçu basin. Hyphessobrycon itaparicensis, UFBA 2687, 3, 28.8-32.7 mm SL, Ilha de Itaparica. Hyphessobrycon micropterus, UFBA 2843, 23.5 $\mathrm{mm}$ SL, rio Itapicuru basin. Hyphessobrycon negodagua, UFBA 4301, 9, 17.4-21.1 mm SL, rio Paraguaçu basin. Hyphessobrycon parvellus, UFBA 4309, 60, 10, 10.3-20.2 mm SL, rio Pojuca basin. Hyphessobrycon vinaceus, UFBA 4608, 10, 34.3-61.7 mm SL, rio Pardo basin.

\section{Acknowledgements}

The paper was benefitted from the comments of Flávio C. T. Lima. We are also grateful to Alexandre B. A. Góes and Rafael Burger for their help during field expeditions, and Adolfo R. Calor for the identification of insects of the stomach contents, and to the Instituto Gonçalo Moniz (FIOCRUZ/BA) for the SEM images. Photographs of preserved fish was produced by Eduardo Baena and Rafael Burger. Funding for field work in which the new species was collected was provided by CNPq (grant\#476449/2007-3). Priscila Camelier had financial help from CAPES. Permission for collecting specimens was granted by IBAMA.

\section{Literature Cited}

Benine, R. C. \& G. A. M. Lopes. 2008. A new species of Hyphessobrycon (Characiformes: Characidae) from Río Portuguesa, Río Orinoco basin, Venezuela. Zootaxa, 1714: 61-68. 
Bertaco, V. A., L. R. Malabarba \& J. A. Dergam. 2007. New Hyphessobrycon from the upper rio Pardo drainage in eastern Brazil (Teleostei: Characiformes: Characidae). Neotropical Ichthyology, 5(3): 245-249.

Carvalho, T. P. \& V. A. Bertaco. 2006. Two new species of Hyphessobrycon (Teleostei: Characidae) from upper rio Tapajós basin on Chapada dos Parecis, central Brazil. Neotropical Ichthyology, 4(3): 301-308.

Carvalho, F. R., F. Langeani, C. S. Miyazawa \& W. P. Troy. 2008. Hyphessobrycon rutiliflavidus $\mathrm{n}$. sp., a new characid fish from the upper rio Paraguai, State of Mato Grosso, Brazil (Characiformes: Characidae). Zootaxa, 1674: 39-49.

Eigenmann, C. H. 1918. The American Characidae. Part 2. Memoirs of the Museum of Comparative Zoology, 43: 101-208.

Ferraris, C. J. Jr. 2007. Checklist of catfishes, recent and fossil (Osteichthyes: Siluriformes), and catalogue of siluriform primary types. Zootaxa, 1418:1-300.

Fink, W. L. \& S. H. Weitzman. 1974. The so-called cheirodontin fishes of Central America with description of two new species (Pisces, Characidae). Smithsonian Contributions to Zoology, 172: 1-46.

Fowler, H. W. 1941. A collection of fresh-water fishes obtained in eastern Brazil by Dr. Rodolpho von Ihering. Proceedings of the Academy of Natural Sciences of Philadelphia, 93: 123-199.

Fowler, H. W. 1948. Os peixes de água doce do Brasil ( $1^{\mathrm{a}}$ entrega). Arquivos de Zoologia do Estado de São Paulo, 6: 1-204.

Garzía-Alzate, C. A., C. Román-Valencia \& D. C. Taphorn. 2010a. A new species of Hyphessobrycon (Teleostei: Characiformes: Characidae) from the San Juan River drainage, Pacific versant of Colombia. Zootaxa, 2349: 55-64.

Garzía-Alzate, C. A., C. Román-Valencia \& D. C. Taphorn. 2010b. Two new species of Hyphessobrycon (Pisces: Characiformes: Characidae) from Putumayo River, with keys to the Colombian Hyphessobrycon heterorhabdus-group species. Brenesia, 70: 33-46.

Géry, J. 1977. Characoids of the World. Neptune City, T. F. H. Publications, 672p.

Lima, F. C. T. \& P. Gerhard. 2001. A new Hyphessobrycon (Characiformes: Characidae) from Chapada Diamantina, Bahia, Brazil with notes on its natural history. Ichthyological Exploration of Freshwaters, 12(2): 105-114.

Menezes, N. A. \& S. H. Weitzman. 1990. Two new species of Mimagoniates (Teleostei: Characidae: Glandulocaudinae), their phylogeny and biogeography and a key to the glandulocaudin fishes of Brazil and Paraguay. Proceedings of the Biological Society of Washington, 103: 380-426.

Miquelarena, A. M. \& H. L. López. 2010. Hyphessobrycon nicolasi (Teleostei: Characidae) a new species from the Uruguay River basin in the Mesopotamian Region, Argentina. Neotropical Ichthyology, 8(1): 1-6.

Taylor, W. R. \& G. C. van Dyke. 1985. Revised procedures for staining and clearing small fishes and other vertebrates for bone and cartilage study. Cybium, 9(2): 107-118.

Weitzman, S. H. \& L. Palmer. 1997. A new species of Hyphessobrycon (Teleostei: Characidae) from the Neblina region of Venezuela and Brazil, with comments on the putative 'rosy tetra clade'. Ichthyological Exploration of Freshwaters, 7(3): 209-242. 